\title{
Thermodynamic Studies on the Interaction of Copper Ions with Carbonic Anhydrase
}

\author{
N. S. Sarraf, S. Mamaghani-Rad, F. Karbassi, and A. A. Saboury ${ }^{*}$ \\ Institute of Biochemistry and Biophysics, University of Tehran,Tehran, Iran. *E-mail: saboury@ut.ac.ir \\ Received November 3, 2004
}

\begin{abstract}
The interaction of bovine carbonic anhydrase II with copper ions was studied by isothermal titration microcalorimetry, circular dichroism, UV spectrophotometry and temperature scanning spectrophotometry methods at $27^{\circ} \mathrm{C}$ in Tris buffer solution at $\mathrm{pH}=7.5$. It was indicated that there are three non-identical different binding sites on carbonic anhydrase for $\mathrm{Cu}^{2+}$. The binding of copper ions is exothermic and can induce some minor changes in the secondary and tertiary structure of the enzyme, which does not unfold it, but can result in a decrease in both activity and stability of the enzyme.
\end{abstract}

Key Words : Carbonic anhydrase, Copper, Titration calorimetry, Circular dichroism, Spectrophotometry

\section{Introduction}

Carbonic anhydrase (CA, EC 4.2.1.1) was discovered in erythrocytes in 1933 by Meldrum and Roughton ${ }^{1}$ and Stadie and O'brien. ${ }^{2}$ This ubiquitous zinc enzyme is present in archaeo and eubacteria, green plants and animals. ${ }^{3,4}$

In addition to catalyzing the reversible hydration of $\mathrm{CO}_{2}$ to bicarbonate,${ }^{5,6} \mathrm{CA}$ is involved in a variety of other reactions, such as hydrolysis of aromatic and aliphatic esters, or the hydration of carbamic acid or cyanate to urea or some other less investigated hydrolytic processes. ${ }^{7-9}$

CA II is novel as a metalloprotein due to its unusually high affinity for zinc, so that the CA II-zinc ${ }^{2+}$ dissociation constant is $1-4 \mathrm{pM} .^{10,11}$ The zinc-binding site resides at the bottom of a 15 - $\AA$-deep active site cleft. ${ }^{12}$ The zinc ion is directly coordinated to three histidine ligands, at positions 94, 96 and 119. These ligands are in turn fixed in position ideal for coordination to the zinc ion by a series of "second shell" ligands that include Gln-92, Asn-244 and Glu-117. A water molecule completes the tetrahedral coordination sphere of zinc, which is hydrogen bonded to Thr-199. ${ }^{12}$

Although CA is loaded with zinc in its physiologically relevant form, it can bind a number of other metal ions in the zinc binding site, such as $\mathrm{Co}(\mathrm{II}), \mathrm{Ni}(\mathrm{II}), \mathrm{Cu}(\mathrm{II}), \mathrm{Cd}(\mathrm{II})$, $\mathrm{Hg}(\mathrm{II})$ and $\mathrm{Pb}(\mathrm{II})$ with varying affinities. ${ }^{10}$ Only the cobalt enzyme retains significant catalytic activity at neutral $\mathrm{pH} .^{12}$ Binding of various metal ions to the apoenzyme CAII has been intensely investigated. Some studies include the coordination geometry characteristics of metals such as $\mathrm{Zn}(\mathrm{II}), \mathrm{Cu}(\mathrm{II}), \mathrm{Co}(\mathrm{II}), \mathrm{Mn}(\mathrm{II})$ and $\mathrm{Ni}(\mathrm{II}),{ }^{12,13}$ thermodynamic parameters such as the heat capacity change $(\Delta \mathrm{Cp})$, enthalpy $(\Delta \mathrm{H})$, standard Gibbs free energy $\left(\Delta \mathrm{G}^{\circ}\right)$ and entropy $(\Delta \mathrm{S})$ for some metal ions such as $\mathrm{Zn}(\mathrm{II}), \mathrm{Co}(\mathrm{II}), \mathrm{Cu}(\mathrm{II}), \mathrm{Cd}(\mathrm{II})$, $\mathrm{Ni}(\mathrm{II})^{14,15}$ and different properties of divalent metal ions substituted enzyme. ${ }^{16,17}$ Such investigations are carried out for either wild type or some variants of the enzyme carbonic anhydrase. $^{18,19}$ Besides, the affinity and selectivity of apoenzyme for different metal ions, has been based for designing CA transducers for biosensing metal ions in complex media, ${ }^{20}$ and also recognition of a unique pattern of histidine residues on the surface of protein, which may then be used for different applications such as protein purification by immobilized metal affinity chromatography (IMAC), etc.. ${ }^{21}$

Most of the studies on the metal ion binding to the CA II have been carried out with the apoenzyme. However, in this study the effect of the copper ion on the structure and activity of the holoenzyme, in addition to some investigations on the binding parameters of $\mathrm{Cu}^{2+}$ to the enzyme has been considered.

\section{Materials and Methods}

Materials. Erythrocyte bovine carbonic anhydrase and $p$ nitrophenylacetate were obtained from Sigma. Copper sulfate was obtained from Merck. The buffer solution used in the experiments was $50 \mathrm{mM}$ Tris, $\mathrm{pH}=7.5$, which was obtained from Merck. All the experiments were carried out in $300 \mathrm{~K}$

Methods.

Enzyme assay: Enzyme activity was assayed using a spectrophotometer with jacketed cell holders by following the increase in absorbance at $400 \mathrm{~nm}$ due to the production of $p$-nitrophenol. ${ }^{8}$ Its temperature was regulated by an external thermostated water circulator within $\pm 0.05{ }^{\circ} \mathrm{C}$. Enzyme was incubated with different concentrations of $\mathrm{Cu}^{2+}$ (the maximum concentration was $5 \mathrm{mM}$ ) and then initial rates of $p$-nitrophenylacetate hydrolysis catalyzed by $\mathrm{CA}$ was determined in the absence and presence of $\mathrm{Cu}^{2+}$. Enzyme and substrate concentrations were $0.3 \mu \mathrm{M}$ and 5 $\mathrm{mM}$, respectively. Nonenzymatic hydrolysis rate was always subtracted from the observed rate. ${ }^{22,23}$ Care was taken to use adequate experimental conditions to keep the enzyme reaction linear during the first minute of reaction.

Spectrophotometric titration of $\mathrm{CA}$ with $\mathrm{Cu}^{2+}$ : Copper ion solution, in the form of $\mathrm{CuSO}_{4}$, was added gradually to a $1000 \mu \mathrm{L}$ solution of enzyme with the concentration of 17 $\mu \mathrm{M}$, and the change in the absorbance of $280 \mathrm{~nm}$ of the enzyme was observed. The concentration of $\mathrm{Cu}^{2+}$ varied from $0.01 \mathrm{mM}$ to $10 \mathrm{mM}$. $\mathrm{Cu}^{2+}$ was added to both sample 
and reference cell. The experiment was repeated with $\mathrm{ZnSO}_{4}$ and $\mathrm{CoSO}_{4}$.

Temperature-scanning spectroscopy: Absorbance profiles, which describe the thermal denaturation of $\mathrm{CA}$, were obtained from a UV-Visible spectrophotometer CARY-100Bio model fitted with a temperature programmer, which controls the speed of temperature change in denaturation experiments. The cuvette holder can accommodate two samples: one as a reference buffer solution and the other one for sample experimental determination. All sample cells had identical concentrations of CA $(0.3 \mathrm{mg} / \mathrm{mL})$ and different concentrations of $\mathrm{Cu}^{2+}$. The recording chart reads the temperature reference line (from the reference cuvette) and the absorbance change at $280 \mathrm{~nm}$ for each of the samples.

Circular dichroism experiments: Circular dichroism (CD) spectra were recorded on a JASCO J-715 spectrophotometer (Japan). The results were expressed as ellipticity $\left[\theta\left(\mathrm{deg} \mathrm{cm}^{2} \mathrm{dmol}^{-1}\right)\right]$ considering a mean amino acid residues weight (MRW) of 112 and weight of $29 \mathrm{kDa}$ for CA..$^{24}$ The molar ellipticity was determined as $[\theta]_{1}=(100 \times$ MRW $\times \theta_{\mathrm{obs}} / \mathrm{cl}$ ), where $\theta_{\mathrm{obs}}$ is the observed ellipticity in degrees at a given wavelength, $\mathrm{c}$ is the protein concentration in $\mathrm{mg} / \mathrm{ml}$ and 1 is the length of the light path in $\mathrm{cm}$. The instrument was calibrated with (+)-10-camphorsulfonic acid,


standard non-hygroscopic ammonium, (+)-10-camphorsulfonate assuming $[\theta]_{290.5}=7910 \mathrm{deg} \mathrm{cm}^{2} \mathrm{dmol}^{-1} \cdot{ }^{26,27}$ The noise in the data was smoothed by using the JASCO J-715 software. This software uses the fast Fourier-transform noise reduction routine that allows enhancement of most noisy spectra without distorting their peak shapes. The JASCO J715 software was used to predict the secondary structure of the protein according to the statistical method. ${ }^{28,29}$

Far-UV CD was carried out in the presence of $0.22 \mathrm{mg} /$ $\mathrm{mL}$ of CA. In Near-UV region higher concentrations of protein should be used due to the low extinction coefficients of the chromophores. Thus $1.12 \mathrm{mg} / \mathrm{mL}$ of CA was applied in Near-UV CD experiments. Consequently, the $\mathrm{Cu}^{2+}$ concentrations were selected so that the stochiometry of the solution held constant.

Isothermal titration calorimetry: The experiments were performed with a 4-channel commercial microcalorimetric system, Thermal Activity Monitor 2277, Thermometric, Sweden. Both sample and reference vessels were made from stainless steel. Copper solution $(10 \mathrm{mM})$ was injected by use of a Hamilton syringe into the calorimetric stirred titration vessel, which contained $2 \mathrm{~mL} \mathrm{CA}, 5$ or $40 \mu \mathrm{M}$, in Tris buffer $(30 \mathrm{mM}), \mathrm{pH}$ 7.5. Thin $(0.15 \mathrm{~mm}$ inner diameter) stainless steel hypodermic needles, permanently fixed to the syringe, reached directly into the calorimetric vessel. Injection of copper solution into the perfusion vessel was repeated 50 times, and each injection included $10 \mu \mathrm{L}$ reagent in the first 30 injections and $20 \mu \mathrm{L}$ reagent in the rest of 20 injections. The calorimetric signal was measured by a digital voltmeter that was part of a computerized recording system. The heat of each injection was calculated by the "Thermometric Digitam 3" software program. The heat of dilution of the copper solution was measured as described above except CA was excluded. Also, the heat of dilution of the protein solution was measured as described above except that the buffer solution was injected to the protein solution in the sample cell. The enthalpies of copper and protein solutions dilution were subtracted from the enthalpy of $\mathrm{CA}-\mathrm{Cu}^{2+}$ interaction. The microcalorimeter was frequently calibrated electrically during the course of the study.

\section{Results and Discussion}

The effect of $\mathrm{Cu}^{2+}$ ions on the structure of the enzyme can be seen through Figure 1. In this figure, it is obvious that adding $\mathrm{Cu}^{2+}$ to $\mathrm{CA}$ induces some change in the absorbance of $280 \mathrm{~nm}$ of the enzyme. This change somehow resembles to an unfolding and/or aggregation curve, in which the absorbance decreases through a sigmoid curve, and finally reaches to a minimum. The midpoint of this curve could be considered as $1 \mathrm{mM}$ of $\mathrm{Cu}^{2+}$. This experiment was repeated with $\mathrm{ZnSO}_{4}$ and $\mathrm{CoSO}_{4}$ to see if the effect is because of ionic strength. However, the results showed no difference in the control absorbance of CA.

To know the probable effects of $\mathrm{Cu}^{2+}$ ions on the structure of $\mathrm{CA}$, the effect of $\mathrm{Cu}^{2+}$ on the activity of $\mathrm{CA}$ was investigated. The result was shown in the Figure 2. This figure depicts the percent of relative activity of the enzyme in the absence and presence of different concentrations of $\mathrm{Cu}^{2+}$. It can be seen that in higher concentrations of $\mathrm{Cu}^{2+}$, the activity of the enzyme decreases, and this effect is more obvious after 3 and 140 hours, so that after 140 hours, the activity of carbonic anhydrase in the presence of $5 \mathrm{mM}$ of $\mathrm{Cu}^{2+}$, goes to near $10 \%$.

To obtain further information on the effect of $\mathrm{Cu}^{2+}$ on the enzyme, the thermal denaturation curves of $\mathrm{CA}$ were obtained through temperature scanning spectroscopy (Fig. 3a). It is observed that the transition temperature $\left(T_{m}\right)$ of $C A$ is altered in the presence of different concentrations of the enzyme (Table 1). The amount of $\Delta \mathrm{G}^{\mathrm{o}}{ }_{25}$ (the standard Gibbs free energy of protein denaturation at $25^{\circ} \mathrm{C}$ ) can be obtained

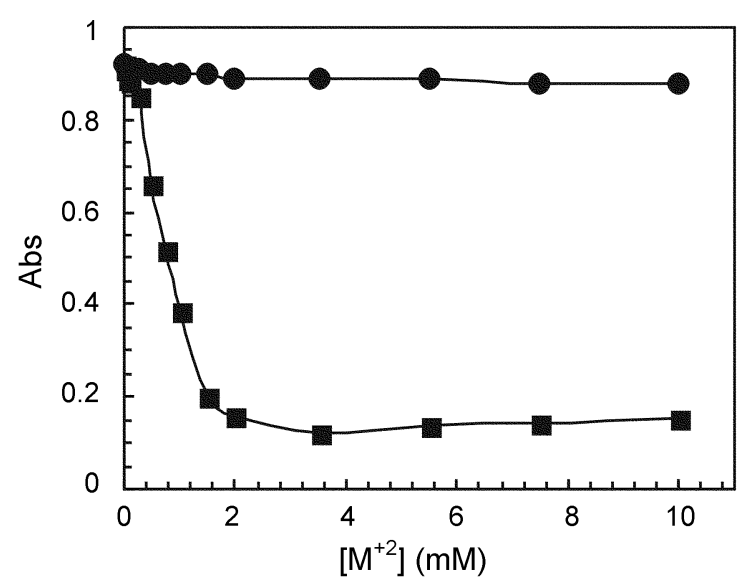

Figure 1. The absorbance change of $280 \mathrm{~nm}$ as a result of titration of carbonic anhydrase by $\mathrm{Cu}^{2+}(\boldsymbol{\square})$ or $\mathrm{Zn}^{2+}$ or $\mathrm{Co}^{2+}(\bullet)$. 


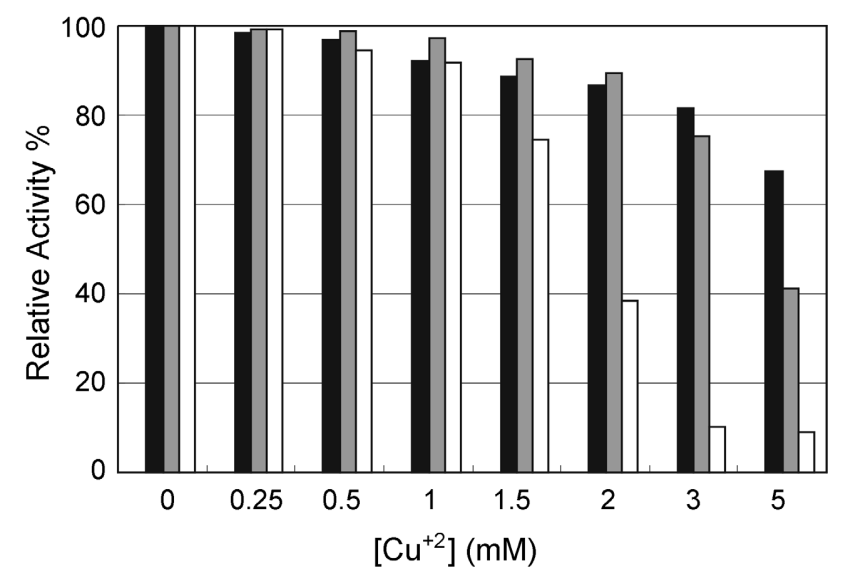

Figure 2. The relative activity of the enzyme in the presence of different concentrations of $\mathrm{Cu}^{2+}$ after $0(\boldsymbol{\square}), 3(\square)$ and $140(\square)$ hours.
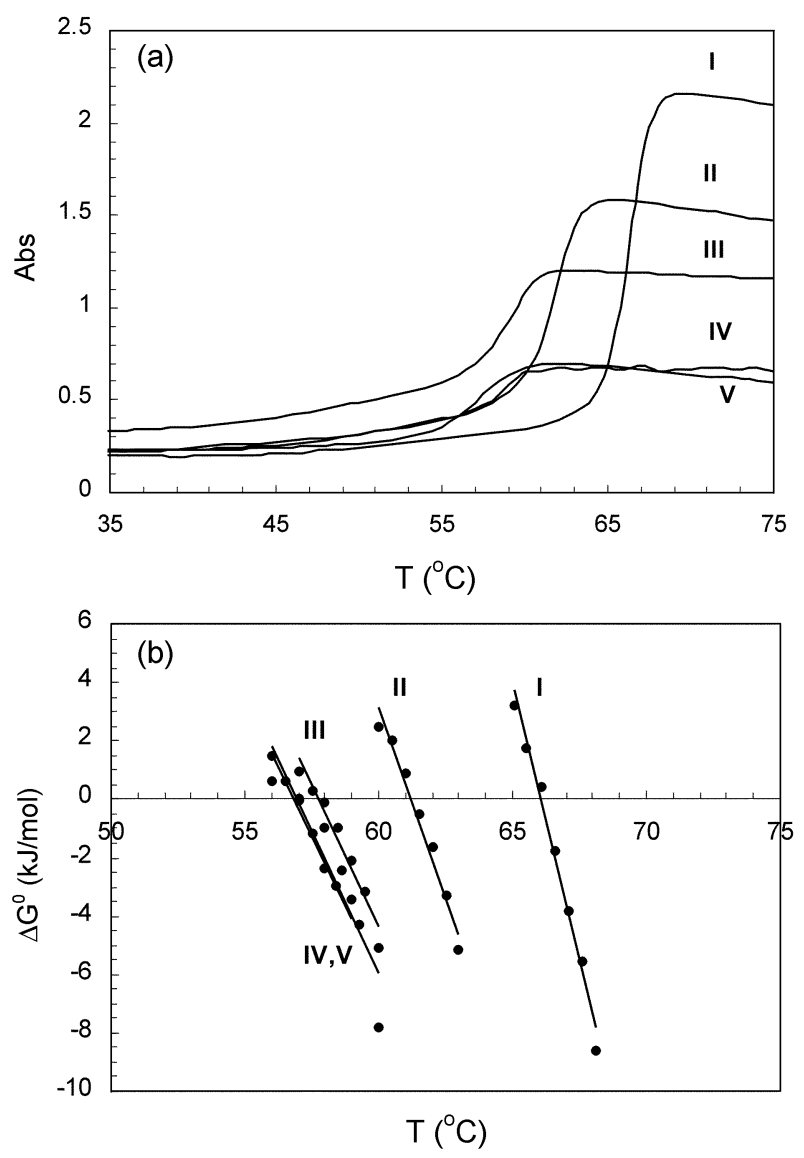

Figure 3. Thermal denaturation profiles of carbonic anhydrase (a) and Gibbs free energy of unfolding plots (b) in the presence of different concentrations of $\mathrm{Cu}^{2+}$ : I) 0 , II) 0.25 , III) 0.5 , IV) 0.75 and V) $1 \mathrm{mM}$. from Pace analysis ${ }^{30}$ of thermal denaturation curves (Fig. 3b). Determination of the standard Gibbs free energy of denaturation $\left(\Delta \mathrm{G}^{\circ}\right)$, as a criterion of conformational stability of a globular protein, is based on two state theory as follows:

$$
\text { Native }(N) \Leftrightarrow \text { Denatured (D) }
$$

This process was described as a single denaturantdependent step according to the two step theory. ${ }^{30}$ By assuming two-state mechanism for protein denaturation by temperature, one can determine the process by monitoring the changes in the absorbance, ${ }^{28,31,32}$ and hence calculate the denatured fraction of protein $\left(\mathrm{F}_{\mathrm{d}}\right)$ as well as determination of the equilibrium constant $(\mathrm{K})$.

$$
\begin{gathered}
F_{d}=\frac{\left(Y_{N}-Y_{o b s}\right)}{\left(Y_{N}-Y_{D}\right)} \\
K=\frac{F_{d}}{\left(1-F_{d}\right)}=\frac{\left(Y_{N}-Y_{o b s}\right)}{\left(Y_{o b s}-Y_{D}\right)}
\end{gathered}
$$

where $Y_{o b s}$ is the observed variable parameter (e.g. absorbance) and $Y_{N}$ and $Y_{D}$ are the values of $Y$ characteristics of a fully native and denatured conformation, respectively. The standard Gibbs free energy change $\left(\Delta G^{\circ}\right)$ for protein denaturation is given by the following equation:

$$
\Delta \mathrm{G}^{\mathrm{o}}=-\mathrm{RT} \ln \mathrm{K}
$$

Where $R$ is the universal gas constant and $T$ is the absolute temperature. $\Delta \mathrm{G}^{\mathrm{o}}$ varies linearly with $T$ over a limited region. The simplest method of estimating the conformational stability in the room temperature, $\Delta \mathrm{G}^{\mathrm{o}}{ }_{25}$, is to assume that linear dependence continues to $25^{\circ} \mathrm{C}$ and to use a least-square analysis. $\Delta \mathrm{G}^{\mathrm{o}}{ }_{25}$ was calculated and shown in Table 1. It can be seen that this parameter is decreasing as like as the $T_{m}$ of the enzyme, and this may be concluded as decreasing the stability of the enzyme.

It would be valuable to take a look at the CD spectra of the enzyme in the absence and presence of different concentrations of $\mathrm{Cu}^{2+}$ (Fig. 4). Figure 4a depicts the CD spectra of $\mathrm{CA}$ in Far-UV region. Detailed structural differences was calculated and reported in Table $2 .{ }^{33}$ As it is seen, there is a general change in the secondary structure of the enzyme, including some decreases in the amount of helix and $\beta$ structures, and an increase in the amount of random coil. On the other hand, Figure $4 \mathrm{~b}$ shows the Near-UV CD spectra of $\mathrm{CA}$ in the absence and presence of $\mathrm{Cu}^{2+}$. These plots show some alterations in different regions related to the aromatic amino acids, which may be considered as the result of some perturbing in the spatial arrangement of amino acids in the enzyme, as a consequence of $\mathrm{Cu}^{2+}$. The figure depicts that the tertiary structure has not been diminished to zero which

Table 1. the amounts of $\mathrm{T}_{\mathrm{m}}$ and $\Delta \mathrm{G}^{\mathrm{o}}{ }_{25}$ for $\mathrm{CA}$ in the presence of different concentrations of $\mathrm{Cu}^{2+}$

\begin{tabular}{cccccc}
\hline$\left[\mathrm{Cu}^{2+}\right](\mathrm{mM})$ & 0 & 0.25 & 0.5 & 0.75 & 1 \\
\hline $\mathrm{T}_{\mathrm{m}}$ & $64.8 \pm 0.2$ & $62.1 \pm 0.2$ & $59.1 \pm 0.2$ & $58 \pm 0.2$ & $57.2 \pm 0.2$ \\
$\Delta \mathrm{G}^{\circ}{ }_{25}(\mathrm{~kJ} / \mathrm{mol})$ & $114 \pm 0.2$ & $93.68 \pm 0.2$ & $63.8 \pm 0.2$ & $62 \pm 0.2$ & $60.2 \pm 0.2$ \\
\hline
\end{tabular}





Figure 4. Far-UV CD spectra (a) and Near-UV CD spectra (b) for carbonic anhydrase in the presence of I) 0 , II) 0.25 , III) 1 and IV) 5 $\mathrm{mM}$ of $\mathrm{Cu}^{2+}$.

Table 2. The amounts of secondary structures of CA in the presence of different concentrations of $\mathrm{Cu}^{2+}$

\begin{tabular}{cccc}
\hline$\left[\mathrm{Cu}^{2+}\right](\mathrm{mM})$ & Helix (\%) & $\beta$-structures $(\%)$ & Random coil (\%) \\
\hline 0 & $21.5 \pm 0.2$ & $34.6 \pm 0.2$ & $43.9 \pm 0.2$ \\
0.25 & $20.8 \pm 0.2$ & $31.8 \pm 0.2$ & $47.4 \pm 0.2$ \\
1 & $20.1 \pm 0.2$ & $30.1 \pm 0.2$ & $47.8 \pm 0.2$ \\
5 & $18.2 \pm 0.2$ & $29.1 \pm 0.2$ & $52.7 \pm 0.2$ \\
\hline
\end{tabular}

could be a criterion of unfolding of CA. However, the small changes in the tertiary structure around some aromatic residues specially a few Trp residues may indicate exposing of some hydrophobic patches, a factor which may make the protein prone to aggregation. ${ }^{34,35}$

It seems that both far and near UV-CD spectra of the enzyme in the presence of $\mathrm{Cu}^{2+}$, show some fine changes in the secondary and tertiary structures of CA. However, none of the alterations indicate unfolding of the enzyme. So it seems that $\mathrm{Cu}^{2+}$ can bind to the enzyme, and as the zinc ion in the active site can not be substituted by the copper ions without any chelating agent, ${ }^{6}$ these ions bind to some sites other than the catalytic site of the enzyme.
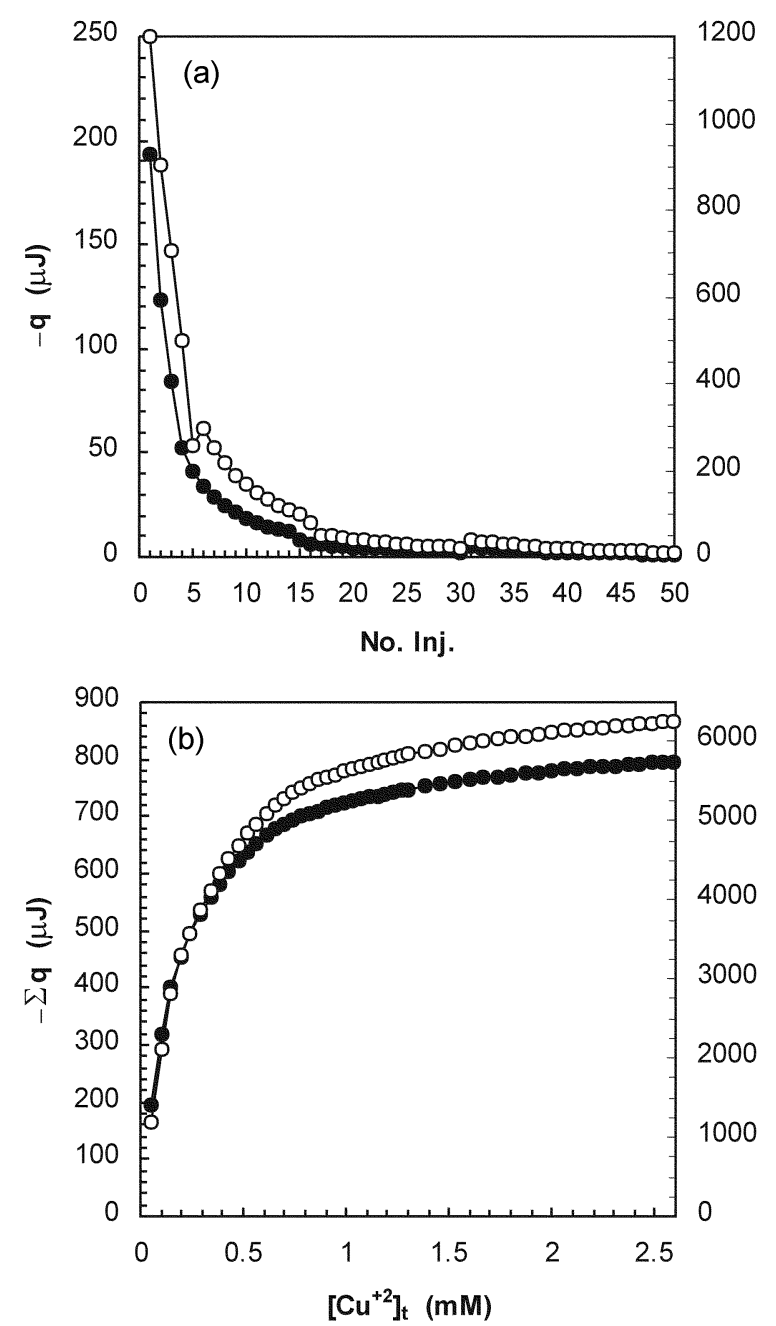

Figure 5. The heat of copper ion binding on CA for 50 injections, each of 10 or $20 \mu \mathrm{L}$ of copper $10 \mathrm{mM}$ into the sample cell containing $2 \mathrm{~mL} \mathrm{CA}$ solution at two concentrations of $5 \mu \mathrm{M}(\bullet)$, left vertical axis, and $40 \mu \mathrm{M}(\bigcirc)$, right vertical axis. Fig. $5 \mathrm{a}$ is showing the heat of each injection and Fig. $5 \mathrm{~b}$ is showing the cumulative heat of related to each total concentration of copper ion, $\left[\mathrm{Cu}^{2+}\right]_{\mathrm{t}}$.

Getting detailed information about these copper binding sites, the isothermal titration calorimetric studies were carried out. The raw data obtained from isothermal titration calorimetry of CA interaction with copper ion in two different concentrations of the protein was shown in Figure 5. Figure 5a is showing the heat of each injection and Figure $5 \mathrm{~b}$ is showing the heat of related to each total concentration of copper ion, $\left[\mathrm{Cu}^{2+}\right]_{\text {t }}$ These raw calorimetric data can be used to show the heat of binding of copper ions per mole of $\mathrm{CA}(\Delta \mathrm{H})$ versus total concentration of copper ions, Figure $6 \mathrm{a}$, or versus total concentration of the protein, Figure $6 \mathrm{~b}$.

Besides, the binding isotherm plot as shown in Figure $7 \mathrm{a}$ and the Scatchard plot, $v /\left[\mathrm{Cu}^{2+}\right]_{\mathrm{f}}$ versus $v$, as shown in Figure $7 \mathrm{~b}$, can be obtained using a simple method of analyzing data, which has previously been used. ${ }^{36,37} v$ is defined as the average moles of bound copper ions per mole of total $\mathrm{CA}$ and $\left[\mathrm{Cu}^{2+}\right]_{\mathrm{f}}$ is the free concentration of copper ions. The base of this simple method is that at any constant 

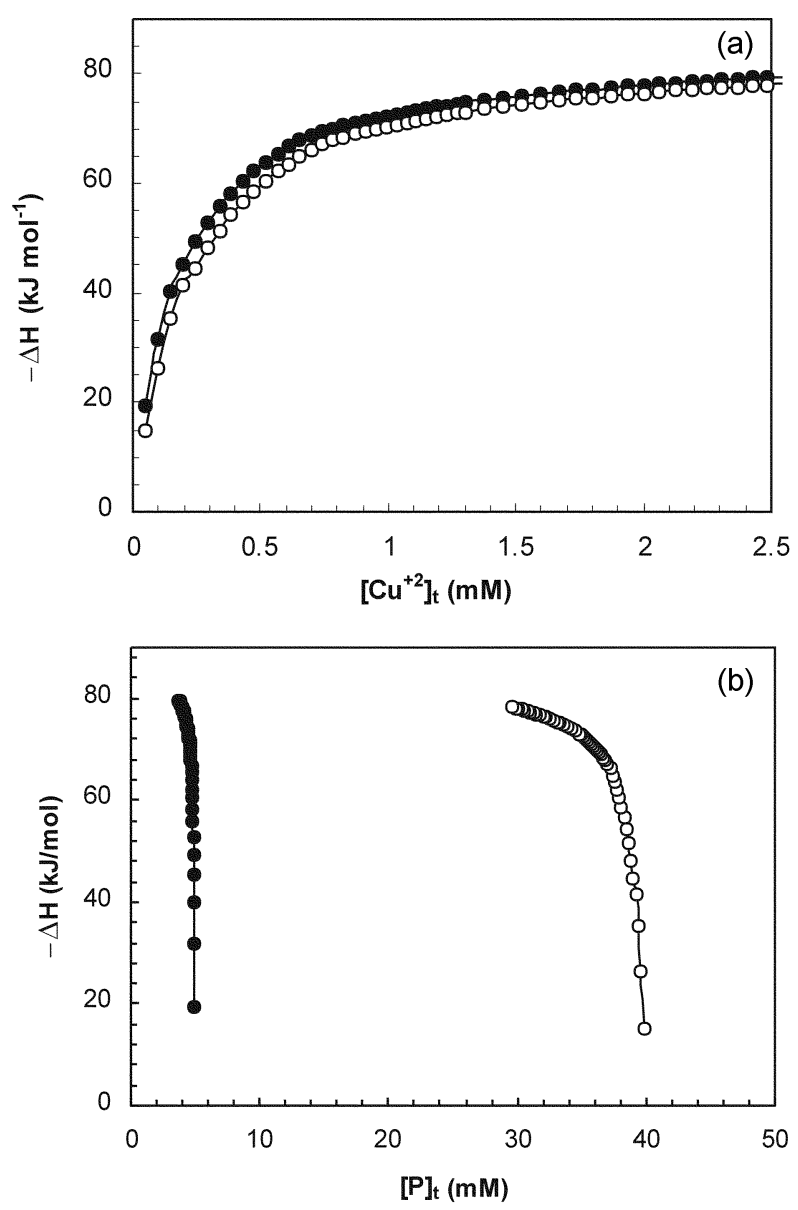

Figure 6. The heat of binding of copper ions per mole of CA versus total concentration of copper ions (a) and versus total concentration of CA (b) at two concentrations of $5(\bullet)$ and $40(\bigcirc) \mu \mathrm{M}$.

value of $\Delta \mathrm{H}, v$ and $\left[\mathrm{Cu}^{2+}\right]_{\mathrm{f}}$ are also constant at equilibrium. This forms the basis by which one can calculate $v$ as a function of $\left[\mathrm{Cu}^{2+}\right]_{\mathrm{f}}$ from a minimum of two titrations. From titrations curves, Figure 7, performed at two different total concentrations $\left(\mathrm{M}_{1}\right.$ and $\left.\mathrm{M}_{2}\right)$, one determine the set of values of the total ligand concentration $\left(\mathrm{L}_{1}\right.$ and $\left.\mathrm{L}_{2}\right)$ for which $\Delta \mathrm{H}$ is constant. This is done by drawing a horizontal line, defining a constant $\Delta \mathrm{H}$ that intersects both titration curves (CA concentrations $\mathrm{M}_{1}$ and $\mathrm{M}_{2}$ ), and determining the values of $\mathrm{L}_{1}$ and $\mathrm{L}_{2}$ at the points of intersection. One can then calculate $\mathrm{n}$ from equation $v=\left(\mathrm{L}_{2}-\mathrm{L}_{1}\right) /\left(\mathrm{M}_{2}-\mathrm{M}_{1}\right)$.

The number of binding sites $(\mathrm{g})$, the binding constant $(\mathrm{K})$ and the Hill coefficient (n) can be obtained by fitting the experiment data to the Hill equation with more than one term: ${ }^{38,39}$

$$
v=\sum_{i=1}^{j} \frac{g_{i} K_{i}\left(\left[\mathrm{Cu}^{2+}\right] f\right)_{i}^{n}}{1+K_{i}\left(\left[\mathrm{Cu}^{2+}\right] f\right)_{i}^{n}}
$$

The binding data for the binding of $\mathrm{Cu}^{2+}$ to $\mathrm{CA}$ have been fitted to the Hill equation using a computer program for nonlinear least-square fitting. ${ }^{40}$ The result indicates that carbonic anhydrase has three sets of single binding sites for copper ion, which show successive intrinsic association
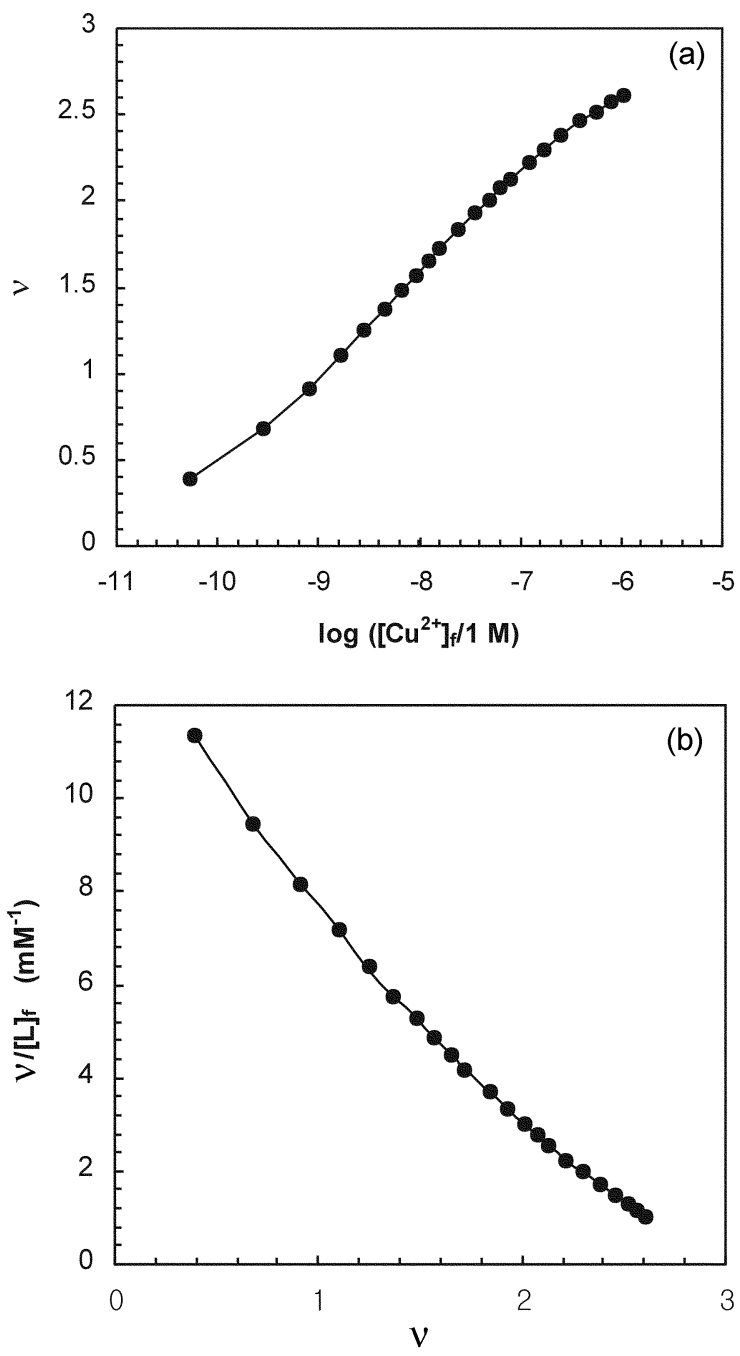

Figure 7. The binding isotherm (a) and the scatchard plot (b) of binding of copper ion by $\mathrm{CA}$ at $27^{\circ} \mathrm{C}$ and $\mathrm{pH}=7.5$.

equilibrium constants: $\mathrm{K}_{1}=9.09 \mathrm{mM}^{-1}, \mathrm{~K}_{2}=3.70 \mathrm{mM}^{-1}$ and $\mathrm{K}_{3}=1.18 \pm 0.02 \mathrm{mM}^{-1}$. Moreover, values of $\Delta \mathrm{H}$ in different values of $v$ (obtained from Fig. 6) give the molar enthalpies of binding $-38.47,-29.76$ and $-18.43 \pm 0.02 \mathrm{~kJ} \mathrm{~mol}^{-1}$ in the first, second and third binding sites, respectively. So the binding processes are exothermic.

In an overall view, it seems that $\mathrm{Cu}^{2+}$ can bind to the enzyme on three different sets of single binding sites other than the catalytic site. This binding can induce some minor structural changes on the enzyme, which does not cause the unfolding of the enzyme, however may be able to increase the propensity for aggregation, which can result in reducing the stability of CA, and a parallel decrease in the activity of the enzyme. Further investigations by fluorescence and light scatteringcan be useful to confirm the possibility of aggregation of CA molecules as a result of binding of copper ions.

Acknowledgements. The financial support of the Research Council of University of Tehran is gratefully acknowledged. 


\section{References}

1. Meldrum, N. U.; Roughton, F. J. W. J. Physiol. 1993, 83,113-141.

2. Stadie, W. C.; O'Brien, H. J. Biol. Chem. 1933, 103, 521-529.

3. Supuran, C. T.; Scozzafava, A.; Casini, A. Med. Res. Rev. 2003, 23, 146-189.

4. Supuran, C. T.; Scozzafava, A. Exp. Opin. Ther. Patent. 2000, 10, 575-600.

5. Coleman, J. E. J. Biol. Chem. 1967, 242, 5212-5219.

6. Lindskog, S.; Coleman, J. E. Proc. Natl. Acad. Sci. USA 1973, 70 , 2505-2508.

7. Sly, W. S.; Peiyi, H. Y. Ann. Rev. Biochem. 1995, 64, 375-401.

8. Pocker, Y.; Stone, J. T. Biochemistry 1967, 6, 668-678.

9. Supuran, C. T.; Conroy, C. W.; Maren, T. H. Proteins: Struct. Funct. Genet. 1997, 27, 272-278.

10. Lindskog, S.; Nyman, P. O. Biochim. Biophys. Acta 1964, 85, 462-474.

11. Kiefer, L. L.; Krebs, J. F.; Paterno, S. A.; Fierke, C. A. Biochemistry 1933, 32, 9896-9900.

12. Hakansson, K.; Carlsson, M.; Svensson, L. A.; Liljas, A. J. Mol. Biol. 1992, 227, 1192-1204.

13. Hakansson, K.; Wehnert, A.; Liljas, A. Acta Crystallogr. 1994, D50, 93-100.

14. DiTusa, C. A.; Christiansen, T.; McCall, K. A.; Fierke, C. A.; Toone, E. J. Biochemistry 2001, 40, 5338-5344.

15. Henkens, R. W.; Watt, G. D.; Sturtevant, J. M. Biochemistry 1969, $5,1874-1878$.

16. Linskog, S. Zinc Enzymes; Spiro, T. G., Ed.; Wiley-Interscience: New York, 1983; pp 77-121.

17. Kogut, K. A.; Rewlett, R. S. J. Biol. Chem. 1987, 262, 1641716424.

18. Cox, J. D.; Hunt, J. A.; Compher, K. M.; Fierke, C. A.; Christianson, D. W. Biochemistry 2000, 39, 13687-13694.

19. DiTusa, C. A.; McCall, K. A.; Christiansen, T.; Mahapatro, M.; Fierke, C. A.; Toone E. J. Biochemistry 2001, 40, 5345-5351.

20. Thompson, R. B.; Maliwal, B. P.; Fierke, C. A. Anal. Biochem. 1999, 267, 185-195.

21. Abul Fazal, M. D.; Roy, B. C.; Sun, S.; Mallik, S.; Rodgers, K. R. J. Am. Chem. Soc. 2001, 123, 6283-6290.
22. Saboury, A. A.; Sarraf, N. S.; Dahot, M. H. Jour. Chem. Soc. Pak. 2004, 26, 69-72.

23. Sarraf, N. S.; Saboury, A. A.; Moosavi-Movahedi, A. A. J. Enz. Inhib. Med. Chem. 2002, 17, 203-207.

24. Wong, K. P.; Hamlin, L. M. Biochemistry 1974, 13, 2678-2682.

25. Schippers, P. H.; Dekkers, H. P. J. M. Anal. Chem. 1981, 53, 778788.

26. Takakuwa, T.; Konno, T.; Meguro, H. Anal. Sci. 1985, 1, $215-218$.

27. Protasevich, I.; Ranjbar, B.; Labachov, V.; Makarov, A.; Gilli, R.; Briand, C.; Lafitte, D.; Haiech, J. Biochemistry 1997, 36, 2017 2024.

28. Yang, J. T.; Wu, C. S. C.; Martinez, H. M. Methods in Enzymology 1986, 130, 208-269.

29. Marthasarathy, P.; Johnson, W. C., Jr. Anal. Biochem. 1987, 167, 76-85.

30. Pace, C. N.; Shiley, B. A.; Thomson, J. A. Protein Structure- A Practical Approach; Creighton, T. E., Ed.; IRL Press: Oxford, 1990; pp 311-330.

31. Moosavi-Movahedi, A. A.; Nazari, K.; Saboury, A. A. Coll. Surf. B: Biointerfaces 1997, 9, 123-130.

32. Saboury, A. A.; Karbassi, F. Thermochim. Acta 2000, 362, 121129.

33. Kelly, S. M.; Price, N. C. Biochem. Biophys. Acta 1997, 1338 , 161-185.

34. Almstedt, K.; Lundqvist, M.; Carlsson, J.; Karlsson, M.; Persson, B.; Jonsson, B.; Carlsson, U.; Hammarstrom, P. J. Mol. Biol. 2004, 342, 619-633.

35. Hammarstrom, P.; Persson, M.; Freskgard, P.; Carlsson, U. J. Biol. Chem. 1999, 274, 32897-32903.

36. Saboury, A. A. J. Therm. Anal. Cal. 2004, 77, 997-1004.

37. Saboury, A. A.; Bagheri, S.; Ataie, G.; Amanlou, M.; MoosaviMovahedi, A. A.; Hakimelahi, G. H.; Cristalli, G.; Namaki, S. Chem. Pharm. Bull. 2004, 52, 1179-1182.

38. Hill, A. V. J. Physiol. 1910, 40, IV-VII.

39. Moosavi-Movahedi, A. A.; Houseindokht, M. R. Int. J. Biol. Macromol. 1994, 16, 77.

40. James, M. L.; Smith, G. M.; Wolford, J. C. Applied Numerical Methods for Digital Computer, $3^{\text {rd }}$ ed.; Harper and Row Publisher: New York, 1985. 